\title{
Regulation of Dio2 gene expression by thyroid hormones in normal and type 1 deiodinase-deficient $\mathrm{C} 3 \mathrm{H}$ mice
}

\author{
Marcia S Wagner, Simone M Wajner, José M Dora and Ana Luiza Maia \\ Endocrine Division, Thyroid Section, Hospital de Clínicas de Porto Alegre, Universidade Federal do Rio Grande do Sul, 2350, 90035-003 Porto Alegre, \\ Rio Grande do Sul, Brazil \\ (Requests for offprints should be addressed to A L Maia; Email: almaia@ufrgs.br)
}

\begin{abstract}
The $\mathrm{C} 3 \mathrm{H} / \mathrm{HeJ}$ mouse presents an inherited type 1 deiodinase (D1) deficiency that results in elevated serum thyroxine $\left(\mathrm{T}_{4}\right)$, whereas TSH and tri-iodothyronine $\left(\mathrm{T}_{3}\right)$ concentrations are normal when compared with those in the C57BL/6J strain. Here, we evaluated the expression of the type 2 (D2), the other $\mathrm{T}_{4}$-activating enzyme, in $\mathrm{C} 3 \mathrm{H}$ mice. A comparative analysis revealed that $\mathrm{D} 2 \mathrm{mRNA}$ levels in $\mathrm{C} 3 \mathrm{H}$ are similar to those in $\mathrm{C} 57$ animals. The $\mathrm{D} 2$ activity in $\mathrm{C} 3 \mathrm{H}$ pituitary and brain are reduced when compared with those in the C57 strain ( $3.75 \pm$ 1.08 vs $5.78 \pm 0.33$ and $0.17 \pm 0.05$ vs $0.26 \pm 0.07 \mathrm{fmol} / \mathrm{min}$ per mg protein respectively). However, no differences on D2 activity levels were observed in the brown adipose tissue (BAT) between both strains $(0 \cdot 34 \pm 0.06$ vs $0.36 \pm$ $0.09 \mathrm{fmol} / \mathrm{min}$ per $\mathrm{mg}$ protein). Experiments using different $\mathrm{T}_{4}$ doses showed that higher levels of serum $\mathrm{T}_{4}$ than those of
\end{abstract}

the $\mathrm{C} 3 \mathrm{H}$ mouse are required to downregulate $\mathrm{D} 2$ activity in this tissue. $T_{3}$ administration to euthyroid mice resulted in a two- to four-fold increase on D2 activity in BAT and brain of both strains, despite a marked decrease in BAT D2 transcripts and no changes in brain D2 mRNA levels. The increase in D2 activity was preceded by a decrease in serum $T_{4}$ levels, which appears to reduce D2 degradation. Indeed, administration of $\mathrm{T}_{3}$ plus $\mathrm{T}_{4}$ abolished the $\mathrm{T}_{3}$-induced $\mathrm{D} 2$ upregulation. In conclusion, our results demonstrated that D2 activity is mainly regulated at posttranslational level in a tissue-specific manner. These observations further characterize and provide insights into the complex and dual regulatory role of the iodothyronines in D2 regulation.

Journal of Endocrinology (2007) 193, 435-444

\section{Introduction}

Thyroxine $\left(\mathrm{T}_{4}\right)$, a major secretory product of the thyroid gland, needs to be converted to tri-iodothyronine $\left(T_{3}\right)$ to exert its biological activity. Two isoenzymes, types 1 and 2 iodothyronine deiodinase (D1 and D2), catalyze $\mathrm{T}_{4}$ to $\mathrm{T}_{3}$ conversion (Bianco et al. 2002). Because high levels of D1 activity were identified in the liver and kidney of rats and humans, it had been assumed that this enzyme was the source of most of the serum $T_{3}$ (Visser 1996). However, recent studies in mice with genetically inactivated hepatic Dio1 demonstrated that the D1 is not essential to maintain normal serum $\mathrm{T}_{3}$ level, at least in the euthyroid state (Streckfuss et al. 2005). D2 plays a critical role in maintaining intracellular $\mathrm{T}_{3}$ level in specialized tissues, such as the anterior pituitary, central nervous system, and brown adipose tissue (BAT; Silva et al. 1978, Crantz et al. 1982, Bianco \& Silva 1987) and, recently, it has been suggested that D2 might also provide a significant fraction of serum $T_{3}$ in euthyroid humans (Maia et al. 2005).

Although several factors such as hormones, growth factors, adrenergic agents, environmental and nutritional conditions influence deiodinase activities, these enzymes are mainly regulated by thyroid hormones (Bianco et al. 2002).
In response to severe iodine deficiency or hypothyroidism, serum $\mathrm{T}_{3}$ and $\mathrm{T}_{4}$ are reduced, thyroid-stimulating hormone (TSH) is increased, and the peripheral $\mathrm{T}_{3}$ production from $\mathrm{T}_{4}$ is maintained by upregulation of D2 and downregulation of D1 expression. Conversely, in the hyperthyroid state D1 is increased, whereas D2 is decreased. D1 activity is regulated by thyroid hormones almost exclusively at the transcriptional level (Berry et al. 1990, Maia et al. 1995a). In contrast, the control of the D2 expression is more complex, occurring by transcriptional, posttranscriptional, and posttranslational mechanisms (St Germain 1988, Burmeister et al. 1997, Gereben et al. 2002). At transcriptional level, D2 is downregulated by its end product $T_{3}$, whereas its substrate, $\mathrm{T}_{4}$, controls enzyme activity at posttranslational level.

The $\mathrm{C} 3 \mathrm{H} / \mathrm{HeJ}(\mathrm{C} 3 \mathrm{H})$ inbred mouse has an inherited D1deficiency which results in approximately tenfold reduction in hepatic levels of D1 mRNA and activity when compared with the C57BL/6J (C57) inbred strain, which presents higher Dio1 expression (Berry et al. 1993, Schoenmakers et al. 1993). In addition to the inherited D1 deficiency, the $\mathrm{C} 3 \mathrm{H}$ mouse exhibits a higher susceptibility to chemically induced hepatocarcinogenesis and lower susceptibility to atherosclerotic plaque formation in response to a high-fat diet and larger spleen, when 
compared with C57 mice (Paigen et al. 1987, Buchmann et al. 1991, Manning \& McDonald 1997). Despite all these known genetic traits, the $\mathrm{C} 3 \mathrm{H}$ mouse presents a mild phenotype in that it appears healthy, and reproduction and growth are unimpaired. The reduced D1 activity in C3H mice correlates with a CGT repeat insertion into the $5^{\prime}$-flanking region of the Dio 1 gene that seems to impair C3H promoter potency (Maia et al. 1995b). The serum $\mathrm{T}_{3}$ and $\mathrm{TSH}$ concentrations in $\mathrm{C} 3 \mathrm{H}$ mice are at normal range, whereas total and free $\mathrm{T}_{4}$ levels are elevated when compared with those in C57 mice. The normal serum $\mathrm{T}_{3}$ is partially explained by the reduction in $\mathrm{T}_{3}$ clearance, due to the lower D1 levels, and increased serum $\mathrm{T}_{4}$ concentration that would compensate for the reduced fractional conversion of $\mathrm{T}_{4}$ to $\mathrm{T}_{3}$. However, the expression of $\mathrm{D} 2$, another $\mathrm{T}_{4}$-activating enzyme, has not been entirely assessed in D1-deficient mice. Comparative analysis of D2 activity levels between $\mathrm{C} 3 \mathrm{H}$ and C57 mice demonstrated that pituitary and brain D2 activity in $\mathrm{C} 3 \mathrm{H}$ mice was about 50\% lower than that in C57 animals (Berry et al. 1993), which is attributed to the twofold increase in serum $\mathrm{T}_{4}$ concentration. The D2 mRNA expression has not been evaluated in the $\mathrm{C} 3 \mathrm{H}$ mouse. In the recently described D1-deficient mouse (D1KO), created by targeted disruption of the Dio1 gene, D2 activity was assessed in pituitary, brain, liver, skin, and thyroid (Schneider et al. 2006). However, D2 expression in BAT, which can be an important source of peripheral $\mathrm{T}_{3}$ under certain circumstances (Silva \& Larsen 1985), was not evaluated.

The aim of the present study was to further investigate Dio2 gene expression and regulation in $\mathrm{C} 3 \mathrm{H}$ D1-deficient mice.

\section{Materials and Methods}

\section{Materials}

All reagents were of analytical grade and obtained from commercial sources. $\mathrm{T}_{4}$ and $\mathrm{T}_{3}$ were obtained from Sigma Chemical Co. High specific activity $\left[{ }^{125} \mathrm{I}\right] \mathrm{T}_{4}(1500 \mu \mathrm{Ci} / \mu \mathrm{g})$ was purchased from Amersham Biosciences. Reagents to determine protein concentration were obtained from BioRad Laboratories.

\section{Animals}

Male C57BL/6J and C3H/HeJ mice (22-28 g), 7 weeks old, obtained from Fundação Estadual de Produção e Pesquisa em Saúde (FEPPS, Porto Alegre, RS, Brazil), were housed under controlled lighting and temperature conditions, and fed a commercial diet and water available ad libitum. The animals were maintained in accordance with the guidelines of the Hospital de Clínicas de Porto Alegre Ethics Committee for the Use and Care of Experimental Animals.

In initial studies, the experimental groups $(n=4-6$ mice/group) included euthyroid control and euthyroid animals treated with $\mathrm{L}_{-} \mathrm{T}_{3}(10 \mu \mathrm{g} / \mathrm{animal}$, i.p. injected, daily) for 3 days before death to induce hyperthyroidism.
Subsequently, the time course of thyroid hormone effects on D2 mRNA and activity in mice tissues was determined using shorter periods of $\mathrm{T}_{3}$ administration. Mice were treated with either saline solution or $10 \mu \mathrm{g} \mathrm{L}-\mathrm{T}_{3}$ for $4,12,24$, and $72 \mathrm{~h}$.

A second series of experiments was conducted to determine the time course of the reduction of D2 activity by maximal doses of $T_{4}$ alone or in combination with $T_{3}$ in tissues of $\mathrm{C} 3 \mathrm{H}$ and $\mathrm{C} 57$ animals. Euthyroid mice were i.p. injected with $\mathrm{L}_{-} \mathrm{T}_{4} 1,3$ or $9 \mu \mathrm{g} / 100 \mathrm{~g} \mathrm{BW}$ alone or a combination of $\mathrm{L}_{-} \mathrm{T}_{4} 3 \mu \mathrm{g} / 100 \mathrm{~g} \mathrm{BW}+\mathrm{L}-\mathrm{T}_{3} 10 \mu \mathrm{g}$ for 6,24 , and $48 \mathrm{~h}$ before death. Mice treated only with vehicle served as euthyroid controls. The chosen doses of administered thyroid hormones were based on previous reports to induce graded thyrotoxicosis (Escobar-Morreale et al. 1997, Schneider et al. 2001). After treatments, mice were euthanized under $\mathrm{CO}_{2}$ and tissues were rapidly removed, frozen in liquid nitrogen, and stored at $-70{ }^{\circ} \mathrm{C}$ until RNA extraction or homogenization for activity analysis.

\section{Serum hormone measurements}

Assays were performed on batched serum samples that had been stored at $-20{ }^{\circ} \mathrm{C}$ awaiting study completion. Serum total $\mathrm{T}_{4}$ was measured by radioimmunoassay (Diagnostic Products Corporation, Los Angeles, CA, USA) and interassay coefficient of variation was $8 \%$. Serum total $\mathrm{T}_{3}$ was also determined by radioimmunoassay in the first series of experiments (Immunotech, Marseille, France) and by electro-quimioluminescence immunoassay (Roche Diagnostics) in experiments shown in Tables 2 and 3. Interassay coefficients of variation were 9 and $10 \%$ respectively.

\section{Isolation of RNA and northern blot analysis}

Total RNA was isolated using TRIzol reagent (Invitrogen Corp.) according to the manufacturer's instructions. Samples of total RNA $(\sim 30 \mu \mathrm{g})$ were examined for the presence of D2 transcripts by northern analysis, using the rat D2 cDNA as probe. Northern blots and radioactive probes were prepared as previously described (Wagner et al. 2003). D2 hybridization signals were quantified by densitometry using Image Master VDS (Pharmacia Biotech). Blots were rehybridized with 18S ribosomal RNA probe and $18 \mathrm{~S}$ signals were used as a control to normalize for differences in the amount of total RNA in samples. All experiments were repeated twice.

\section{Real-time PCR analysis}

RNA was reverse-transcribed with the SuperScript Preamplification System for First Strand cDNA Synthesis (Invitrogen, Corp.) using $3 \mu \mathrm{g}$ total RNA and $100 \mathrm{ng}$ random hexamers. Reactions for the quantification of target mRNAs were performed in an ABI Prism 7500 Sequence Detection System (Applied Biosystems, Warrington, UK) using the SYBR Green PCR Master Mix (Applied Biosystems) and cyclophilin as a housekeeping internal 
control. Samples were run in duplicate. The cycle conditions were $94{ }^{\circ} \mathrm{C} \times 5 \mathrm{~min}$ (Hot Start), 35 cycles of $94{ }^{\circ} \mathrm{C} \times 30 \mathrm{~s}$; $58{ }^{\circ} \mathrm{C} \times 30 \mathrm{~s} ; 72{ }^{\circ} \mathrm{C} \times 45 \mathrm{~s}$ and a final $5 \mathrm{~min}$ extension period. Initially, standard curves representing five-point serial dilution of mixed cDNAs of the control and experimental groups were analyzed and used as calibrators to determine the relative quantification of product generated in the exponential phase of the amplification curve. Comparable efficiency was observed presenting $r^{2}>0.99$. Samples were measured by relative quantification (change in expression $\mathrm{C} 3 \mathrm{H}$ versus $\mathrm{C} 57$ mice; untreated versus treated animals). The data generated by the ABI Prism 7500 system SDS software (Applied Biosystems, Warrington, UK) were then transferred to an Excel spreadsheet and the experimental values corrected by that of the cyclophilin standard. Oligonucleotides for mouse D2 and cyclophilin respectively, were as follows: $\left(5^{\prime}-\right.$ TTCTCCAACTGCCTCTTCCTG-3' and $5^{\prime}$-CCCATCAGCGGTCTTCTCC-3'); (5'-GCCGATGACGAGCC CTTG- $3^{\prime}$ and $5^{\prime}$ TGCCGCCAGTGCCATTATG-3' ${ }^{\prime}$ ).

\section{Deiodinase assays}

$5^{\prime}$-Deiodinase assays were performed as previously described (Wagner et al. 2003). Briefly, tissues samples were homogenized on ice in buffer containing $1 \times \mathrm{PE}(0 \cdot 1 \mathrm{M}$ potassium phosphate and $1 \mathrm{mM}$ EDTA), $0 \cdot 25 \mathrm{M}$ sucrose, and $10 \mathrm{mM}$ dithiothreitol (DTT; pH 6.9). The reaction mixtures containing 100-300 $\mu \mathrm{g}$ tissue protein were incubated in a total volume of $300 \mu \mathrm{l}$ with $\sim 100000$ c.p.m. $\left[3^{\prime}, 5^{\prime}-{ }^{125} \mathrm{I}^{\mathrm{T}} \mathrm{T}_{4}\right.$ purified by LH-20 column chromatography (Pharmacia), $1 \mathrm{nM}(\mathrm{D} 2)$ or $1 \mu \mathrm{M}$ (D1) unlabeled $\mathrm{T}_{4}, 10$, or $20 \mathrm{mM}$ DTT, in the presence or absence of $1 \mathrm{mM}$ propylthiouracil in $\mathrm{PE}$ buffer at $37^{\circ} \mathrm{C}$ for $2 \mathrm{~h}$. Reactions were terminated by the addition of $200 \mu \mathrm{l}$ horse serum and $100 \mu \mathrm{l} 50 \%$ trichloroacetic acid. After centrifugation at $3000 \mathrm{~g}$ for $2 \mathrm{~min}$, the free ${ }^{125} \mathrm{I}$ in the supernatant was counted with a gamma-counter. Deiodination was linear with both protein concentration and time, and the quantity of enzyme assayed was adjusted to consume $<30 \%$ of substrate. Activity is expressed as fentomoles iodide generated/min per $\mathrm{mg}$ protein. In determining deiodination activity, the percent iodide generated was multiplied by two to account for the random labeling and deiodination at the $3^{\prime}$ and $5^{\prime}$ positions in the $\left[3^{\prime}, 5^{\prime}-{ }^{125} \mathrm{I}_{\mathrm{T}} \mathrm{T}_{4}\right.$ (Kuiper et al. 2002). All reactions were performed in duplicate.

\section{Statistical analysis}

Results are presented as mean \pm s.D. of two experiments. Four to six animals were used per group per experiment. Data were log-transformed prior to analysis. Comparisons among groups were assessed by one-way ANOVA followed by Dunnett's post hoc test. $P<0 \cdot 05$ was considered statistically significant.

\section{Results}

\section{D1 activity in $\mathrm{C} 3 \mathrm{H}$ mice}

To confirm that the $\mathrm{C} 3 \mathrm{H}$ mice used in this study present the described D1 deficiency, we determined the level of hepatic D1 activity and compared it with that of the C57 mice. D1 activity in the $\mathrm{C} 3 \mathrm{H}$ mouse was significantly lower than that observed in the C57 strain $(0 \cdot 08 \pm 0 \cdot 04$ vs $0 \cdot 41 \pm 0 \cdot 12 \mathrm{pmol} / \mathrm{min}$ per $\mathrm{mg}$ protein respectively). Accordingly, the serum $\mathrm{T}_{4}$ concentration in $\mathrm{C} 3 \mathrm{H}$ mice was approximately twice that in $\mathrm{C} 57$ animals $(6 \cdot 0 \pm 0.9$ vs $3.4 \pm 0.5 \mu \mathrm{g} / \mathrm{dl})$, whereas $\mathrm{T}_{3}$ levels were comparable between both mice strains $(51 \cdot 3 \pm 22 \cdot 2$ vs $51 \cdot 5 \pm 8 \cdot 9 \mathrm{ng} / \mathrm{dl})$.

\section{D2 $m R N A$ and activity levels}

D2 mRNA and activity were assessed in pituitary, brain, and BAT from $\mathrm{C} 3 \mathrm{H}$ and $\mathrm{C} 57$ mice. The D2 mRNA levels in $\mathrm{C} 3 \mathrm{H}$ tissues were similar to those observed in corresponding tissues in $\mathrm{C} 57$ animals. In the $\mathrm{C} 3 \mathrm{H}$ mouse, D2 activity in pituitary and brain was approximately half of that found in the C57 strain (Table 1). However, interestingly, the level of D2 activity in BAT was similar between both mice strains.

Effects of the administration of different doses of $T_{4}$ on pituitary and BAT D2 activity levels in the $\mathrm{C} 3 \mathrm{H}$ and $\mathrm{C} 57$ mice

Assuming that, in $\mathrm{C} 3 \mathrm{H}$ mice, lower D2 activity levels in the brain and pituitary were due to their chronically elevated

Table 1 Basal levels of deiodinase (D2) expression in C3H and C57 mice. Data are presented as the means \pm s.D. of values obtained in a minimum of four to six mice/group

\begin{tabular}{|c|c|c|c|c|c|c|}
\hline & \multicolumn{2}{|l|}{ BAT } & \multicolumn{2}{|l|}{ Brain } & \multicolumn{2}{|l|}{ Pituitary } \\
\hline & mRNA & Activity & mRNA & Activity & mRNA & Activity \\
\hline \multicolumn{7}{|l|}{ Strain } \\
\hline $\mathrm{C} 3 \mathrm{H} / \mathrm{HeJ}$ & $5 \cdot 95 \pm 5 \cdot 95$ & $0 \cdot 34 \pm 0.06$ & $1 \cdot 82 \pm 0 \cdot 30$ & $0 \cdot 17 \pm 0 \cdot 05$ & $3 \cdot 50 \pm 1 \cdot 83$ & $3 \cdot 75 \pm 1 \cdot 08$ \\
\hline $\mathrm{C} 57 \mathrm{BL} / 6 \mathrm{~J}$ & $5 \cdot 29 \pm 4 \cdot 66$ & $0.36 \pm 0.09$ & $2 \cdot 06 \pm 0 \cdot 81$ & $0 \cdot 26 \pm 0.07$ & $3 \cdot 96 \pm 1 \cdot 41$ & $5 \cdot 78 \pm 0 \cdot 33$ \\
\hline$P$ & $0 \cdot 34$ & $0 \cdot 72$ & $0 \cdot 45$ & $0 \cdot 01$ & $0 \cdot 64$ & $0 \cdot 04$ \\
\hline
\end{tabular}

Measurements of D2 mRNA (arbitrary units), determined by real-time PCR, and activity levels (fmols $\mathrm{T}_{4} / \mathrm{min}$ per mg protein) were performed as described in Materials and Methods. 
serum $\mathrm{T}_{4}$ concentration, we wished to test whether higher levels of circulating $\mathrm{T}_{4}$ would reduce BAT D2 activity in these animals. Therefore, we used a number of different $\mathrm{T}_{4}$ doses to induce a graded increase in the level of serum $\mathrm{T}_{4}$ and correlate them with the D2 activity in BAT and also in pituitary. The latter was used as a reference tissue.

The changes in serum $\mathrm{T}_{4}$ concentration of mice injected with different doses of $T_{4}$ are shown in Fig. 1A. Serum $T_{4}$ was well above control levels by $24 \mathrm{~h}$ after the injection of either

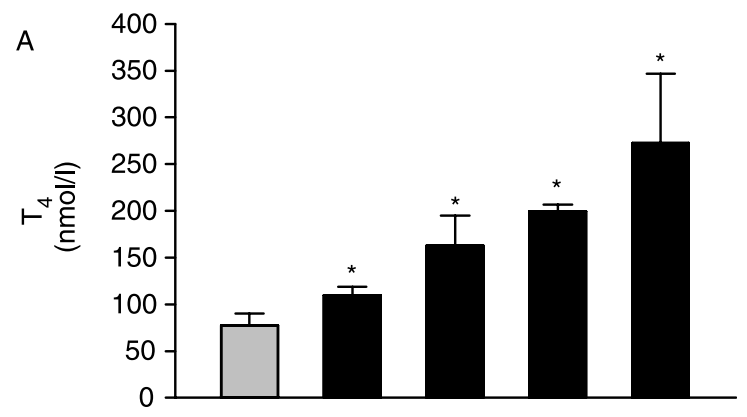

B

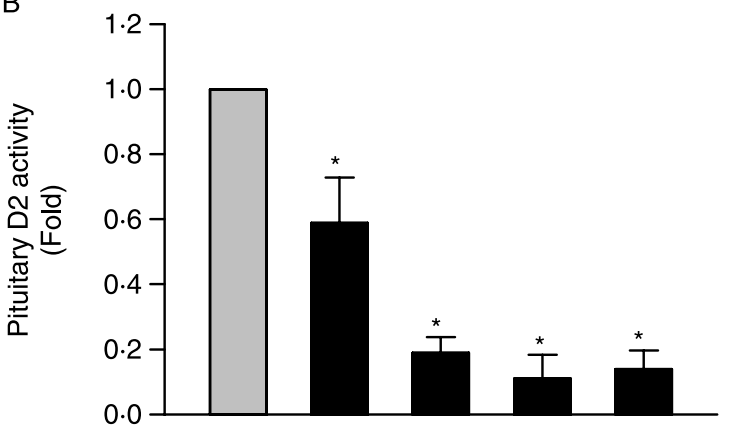

C

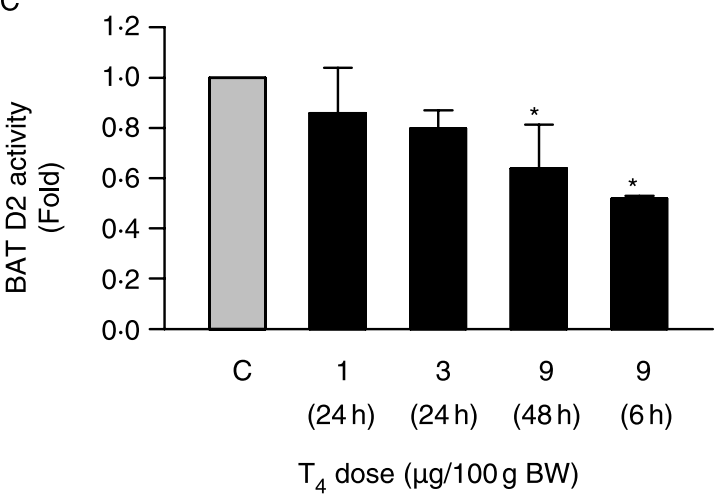

Figure 1 Serum $\mathrm{T}_{4}$ and pituitary and BAT D2 activities in euthyroid $\mathrm{C} 3 \mathrm{H}$ mice injected with different doses of $\mathrm{T}_{4}$. A, Changes in serum $\mathrm{T}_{4}$ concentration in mice injected with vehicle (C) or with increasing doses of $\mathrm{T}_{4}(1$ or $3 \mu \mathrm{g} \mathrm{T} / 100 \mathrm{~g} \mathrm{BW}$ for $24 \mathrm{~h}$ or $9 \mu \mathrm{g}$ $\mathrm{T}_{4} / 100 \mathrm{~g}$ BW for 6 or $48 \mathrm{~h}$, as indicated). B and C, Effects of the different doses of $\mathrm{T}_{4}$ on pituitary (B) and BAT (C) D2 activities. Data are reported as the means \pm s.D. shown relative to controls. $* P<0 \cdot 05$ versus control.
1 or $3 \mu \mathrm{g} \mathrm{T} / 100 \mathrm{~g} \mathrm{BW}$ and reached the highest level by $6 \mathrm{~h}$ after animals were injected with $9 \mu \mathrm{g} \mathrm{T}_{4} / 100 \mathrm{~g} \mathrm{BW}$. A subsequent significant decrease in $\mathrm{C} 3 \mathrm{H}$ pituitary $\mathrm{D} 2$ activity was observed with increasing circulating $\mathrm{T}_{4}$ concentrations (Fig. 1B). On the contrary, no significant changes in BAT D2 activity were observed until serum $\mathrm{T}_{4}$ was approximately threefold higher than $\mathrm{C} 3 \mathrm{H}$ control level (Fig. 1C).

BAT and pituitary D2 activities were also measured in the $\mathrm{T}_{4}$-treated C57 mice to assess whether it presented the same relative insensitivity to changes in circulating $\mathrm{T}_{4}$ as that observed in the $\mathrm{C} 3 \mathrm{H}$ strain. Small increases in serum $\mathrm{T}_{4}$ concentration in C57 mice induced a marked decrease on pituitary D2 activity (Table 2). However, similarly to what has been seen in the $\mathrm{C} 3 \mathrm{H}$ mouse, no significant changes on BAT D2 activity was observed even when serum $\mathrm{T}_{4}$ concentration was approximately threefold higher than control level (Table 2).

Effect of $T_{3}$ administration on $\mathrm{D} 2 m R N A$ and activity levels in $\mathrm{C} 3 \mathrm{H}$ and $\mathrm{C} 57$ mice

To evaluate the intrinsic responsiveness and regulation of the $\mathrm{C} 3 \mathrm{H}$ Dio2 gene by $\mathrm{T}_{3}$, we analyzed the $\mathrm{D} 2 \mathrm{mRNA}$ and activity in brain and BAT of euthyroid mice $\mathrm{T}_{3}$-treated for 3 days. $T_{3}$ administration resulted in a significant decrease in BAT D2 mRNA level in both strains (Fig. 2A and B), whereas no changes were observed in D2 mRNA concentration in the brain (Fig. 2C and D).

Despite the marked decrease in BAT D2 mRNA level, chronic $\mathrm{T}_{3}$ treatment caused a significant increase in BAT and brain D2 activity of both $\mathrm{C} 3 \mathrm{H}$ and $\mathrm{C} 57$ mice (Fig. 3A and $\mathrm{B}$ ). The most likely explanation for the observed $\mathrm{T}_{3}$-induced increase in D2 activity was the reduction of serum $T_{4}$ concentration, due to the decreased thyroid $\mathrm{T}_{4}$ secretion caused by $\mathrm{T}_{3}$-induced inhibition of TSH release. In this case, one could predict that D2 activity levels would increase earlier in tissues of $\mathrm{C} 57$ than in $\mathrm{C} 3 \mathrm{H}$ animals in response to $\mathrm{T}_{3}$ treatment, since the latter presents higher $T_{4}$ concentration and reduced fractional clearance by D1 (Table 3 ). Indeed, BAT D2 activity increased as early as $4 \mathrm{~h}$ after $\mathrm{T}_{3}$ administration in the C57 mouse (Fig. $4 \mathrm{~A}$ and Table 3). D2 activity reached the highest level at $24 \mathrm{~h}$ and remained elevated up to 72 h of treatment (Fig. 4A). In contrast, in $\mathrm{C} 3 \mathrm{H}$ mice, BAT D2 activity did not change significantly at 4-24 h after $\mathrm{T}_{3}$ administration (Table 2). By $72 \mathrm{~h}$ of $\mathrm{T}_{3}$ exposure, BAT D2 activity was similarly higher in both mice strains.

The changes induced by $72 \mathrm{~h} \mathrm{~T}_{3}$ treatment on D2 activity in brain resembled those in BAT. However, short times of exposure to $\mathrm{T}_{3}(4-24 \mathrm{~h})$ did not change significantly the D2 activity levels neither in this tissue in $\mathrm{C} 57$ nor in $\mathrm{C} 3 \mathrm{H}$ animals (Fig. 4B).

\section{Effects of combined $T_{3}$ plus $T_{4}$ treatment on $D 2$ activity levels}

In order to determine whether $\mathrm{T}_{3}$ stimulation of $\mathrm{D} 2$ activity in mice tissues was caused by a $T_{3}$-induced fall in serum $\mathrm{T}_{4}$ concentration, C57 mice were injected with a 
Table 2 Effects of thyroxine $\left(\mathrm{T}_{4}\right)$ administration on thyroid hormones concentrations and pituitary and brown adipose tissue (BAT) deiodinase (D2) activities in the C57 mice. Values are the means \pm s.D. from determinations in four to six mice

\begin{tabular}{|c|c|c|c|c|c|}
\hline & Time (h) & $\mathbf{T}_{3}(\mathrm{nmol} / \mathrm{l})$ & $\mathbf{T}_{\mathbf{4}}(\mathrm{nmol} / \mathrm{l})$ & $\begin{array}{l}\text { Pituitary D2 activity } \\
\text { (fmol/min per } \mathrm{mg} \\
\text { protein) }\end{array}$ & $\begin{array}{l}\text { BAT D2 activity } \\
\text { (fmol/min per } \mathrm{mg} \\
\text { protein) }\end{array}$ \\
\hline Control & 6 & $1 \cdot 90 \pm 0 \cdot 43$ & $53 \cdot 8 \pm 6 \cdot 43$ & $3 \cdot 72 \pm 2 \cdot 65$ & $0 \cdot 86 \pm 0 \cdot 40$ \\
\hline & & $1 \cdot 59 \pm 0 \cdot 13$ & $100 \pm 20 \cdot 6$ & $1 \cdot 27 \pm 0.58^{*}$ & $0.81 \pm 0.25$ \\
\hline (3 $\mu \mathrm{g})$ & & $1.93 \pm 0.26$ & $196 \pm 73 \cdot 4$ & $0.74 \pm 0.36 *$ & $0.64 \pm 0.25$ \\
\hline Control & 24 & $1.43 \pm 0.04$ & $55 \cdot 3 \pm 5 \cdot 15$ & $1 \cdot 74 \pm 0.74$ & $0 \cdot 87 \pm 0 \cdot 30$ \\
\hline $4(1 \mu \mathrm{g})$ & & $1 \cdot 24 \pm 0 \cdot 12$ & $52 \cdot 8 \pm 5 \cdot 15$ & $1 \cdot 59 \pm 0.45$ & $0 \cdot 96 \pm 0 \cdot 10$ \\
\hline $4(3 \mu \mathrm{g})$ & & $1 \cdot 34 \pm 0 \cdot 05$ & $86 \cdot 3 \pm 5 \cdot 15$ & $0 \cdot 38 \pm 0 \cdot 07^{*}$ & $0.69 \pm 0.13$ \\
\hline
\end{tabular}

Mice were i.p. injected with 1 or $3 \mu \mathrm{g} \mathrm{T} / 400 \mathrm{~g} \mathrm{BW}$ and serum thyroid hormones concentrations and D2 activities were determined (A) 6 or (B) $24 \mathrm{~h}$ after each treatment. Control animals received the appropriate vehicle injections. ${ }^{*}$ Significantly different from control $(P<0 \cdot 05)$.

combination of $\mathrm{T}_{4}$ plus $\mathrm{T}_{3}$. After $24 \mathrm{~h}$ of treatment with the combined doses of $10 \mu \mathrm{g} \mathrm{T}_{3}+3 \mu \mathrm{g} \mathrm{T}_{4} / 100 \mathrm{~g} \mathrm{BW}$, circulating $\mathrm{T}_{3}$ was approximately fivefold higher than the control, while $\mathrm{T}_{4}$ did not decrease or exceed normal control values (Table 4). In contrast to the observed $\sim 3 \cdot 5$-fold increase in C57 BAT D2 activity after $\mathrm{T}_{3}$ treatment alone, the administration of $\mathrm{T}_{3}$ plus $\mathrm{T}_{4}$ did not change BAT D2 activity significantly (Table 4).

\section{Discussion}

We have evaluated the Dio2 gene expression in D1-deficient $\mathrm{C} 3 \mathrm{H}$ mice. Our data showed a similar D2 mRNA profile in $\mathrm{C} 3 \mathrm{H}$ and $\mathrm{C} 57$ mice tissues. In euthyroid $\mathrm{C} 3 \mathrm{H}$ animals, due to the increased level of serum $\mathrm{T}_{4}$ concentration, pituitary and brain D2 activities are markedly reduced when compared with C57 mice. Nevertheless, BAT D2 activity is similar between the $\mathrm{C} 3 \mathrm{H}$ and $\mathrm{C} 57$ animals. The results of $\mathrm{T}_{4}$ dose-response experiments showed that higher levels of serum $\mathrm{T}_{4}$ than those of the $\mathrm{C} 3 \mathrm{H}$ mouse are required for $\mathrm{D} 2$ downregulation in this tissue. $\mathrm{T}_{3}$ administration to euthyroid mice resulted in a $\sim 2.5$ - to 4 -fold increase in brain and BAT D2 activity respectively in both mice strains. The increase in D2 activity was not an effect of $\mathrm{T}_{3}$ per se but the result of $\mathrm{T}_{3}$-induced fall in serum $\mathrm{T}_{4}$ concentration, since combined $\mathrm{T}_{3}$ plus $\mathrm{T}_{4}$ administration completely abolished it.

The $\mathrm{C} 3 \mathrm{H}$ inbred mouse strain has an inherited D1 deficiency. Besides the reduced hepatic and renal D1 activity, the most notable features of the $\mathrm{C} 3 \mathrm{H}$ mouse are that, when compared with the C57 mouse, the circulating levels of $\mathrm{T}_{4}$ and $\mathrm{rT}_{3}$ are elevated, while those of TSH and $\mathrm{T}_{3}$ are unchanged. It would therefore be anticipated that in $\mathrm{C} 3 \mathrm{H}$ mice the higher serum free $\mathrm{T}_{4}$ concentration would cause a decrease in D2 activity, which was confirmed by twofold lower D2 activity in pituitary and brain (Berry et al. 1993). Here, we demonstrated that the D2 mRNA levels are not different between $\mathrm{C} 3 \mathrm{H}$ and $\mathrm{C} 57$ mice, providing additional evidence that the reduced $\mathrm{D} 2$ activity in $\mathrm{C} 3 \mathrm{H}$ mice results from an increased rate of substrate-induced enzyme inactivation. Interestingly, in the recently described D1KO mouse, the pituitary D2 activity is not reduced when compared with wild type animals, despite a significant increase in serum $T_{4}$ concentration (Schneider et al. 2006). Since serum $\mathrm{T}_{4}$ in the $\mathrm{D} 1 \mathrm{KO}$ mice is $\sim 50 \%$ increased, while in the $\mathrm{C} 3 \mathrm{H}$ is nearly doubled, a possible explanation for this paradoxical observation would be that this relatively smaller elevation in circulating $\mathrm{T}_{4}$ would not be enough to downregulate pituitary D2 activity. Nevertheless, similar increase in serum $\mathrm{T}_{4}$ concentration $(\sim 60 \%)$ in the C57 mice induces a marked decrease in pituitary D2 activity (Table 2). Thus, it is conceivable, as suggested by Schneider et al. (2006), that some modification in the set point of the feedback system might have occurred during the development of the D1KO mouse.

An unexpected finding of this study was the lack of difference in BAT D2 activity between $\mathrm{C} 3 \mathrm{H}$ and $\mathrm{C} 57$ mice strains. A major D2 property that characterizes its homeostatic behavior is a short half-life ( $\sim 40 \mathrm{~min})$ that can be further reduced by exposure to its substrates, $\mathrm{T}_{4}$ or $\mathrm{rT}_{3}$ (Leonard et al. 1984, Silva \& Leonard 1985). The cellular mechanism for substrate-induced inactivation of D2 involves ubiquitination, which accelerates enzyme degradation through the ubiquitinproteasome pathway (Steinsapir et al. 1998, 2000, Gereben et al. 2000). This regulatory feedback loop efficiently controls $\mathrm{T}_{3}$ production and intracellular $\mathrm{T}_{3}$ concentration based on the amount of $\mathrm{T}_{4}$ available. Indeed, as shown here (Fig. 4) and by others (Croteau et al. 1996), decreases in serum $\mathrm{T}_{4}$ level upregulate BAT D2 activity several times. Hence, it was reasonable to anticipated, based on the higher $\mathrm{C} 3 \mathrm{H}$ serum $\mathrm{T}_{4}$ level, that BAT D2 activity would be lower in these mice. Experiments using high doses of $\mathrm{T}_{4}$ administration demonstrated that $\mathrm{T}_{4}$-induced $\mathrm{D} 2$ downregulation in BAT requires a much higher $\mathrm{T}_{4}$ level than those observed in the $\mathrm{C} 3 \mathrm{H}$ mice (approximately four- to fivefold over C57 serum $\mathrm{T}_{4}$ concentration). The relative resistance of BAT D2 activity to serum $\mathrm{T}_{4}$ levels, in the transition from euthyroidism to hyperthyroidism, was further confirmed in C57 mice (Table 2).

In rodents, BAT is a site of complex interactions between the sympathetic nervous system and thyroid hormone, which make difficult to interpret the already intricate $\mathrm{D} 2$ regulation in this tissue (Bianco et al. 2005). D2 plays a critical role in 


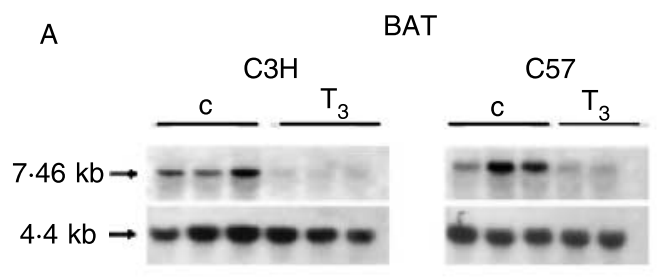

B
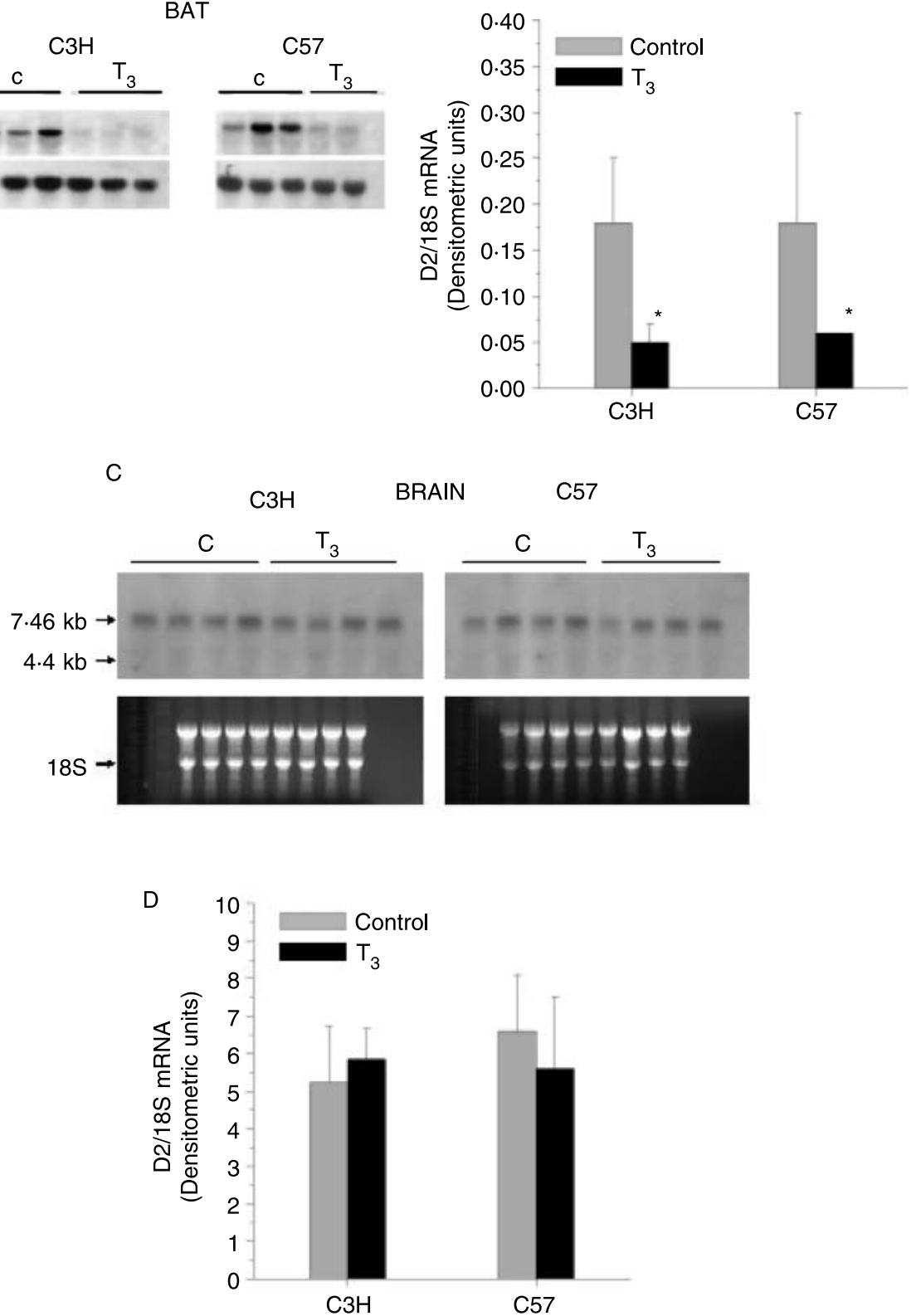

Figure 2 Comparison of D2 mRNA levels in brown adipose tissue (BAT) and brain from control (C) and $\mathrm{T}_{3}$ treated $\left(\mathrm{T}_{3}\right) \mathrm{C} 3 \mathrm{H}$ and $\mathrm{C} 57$ mice. A and C: northern blot analysis of D2 transcripts in BAT and brain. Each lane represents $30 \mu \mathrm{g}$ total RNA obtained from an individual mouse. The blots were probed for D2, and then reprobed for $18 \mathrm{~S}$ ribosomal RNA as described in Materials and Methods. The ethidium bromide-stained image of the 18S RNA is shown for brain blot. B and D: Quantification of the relative intensity of each pair of bands (D2/18S) was performed by densitometry. Bars indicate the means \pm s.D. of values obtained in a minimum of three animals. The experiments were performed twice.

BAT adaptive thermogenesis and similarly to the pituitary and other D2-expressing tissues, BAT is quite dependent on $\mathrm{D} 2$-generated $\mathrm{T}_{3}$ to supply nuclear $\mathrm{T}_{3}$-receptor (de Jesus et al. 2001). Therefore, a decrease in D2 activity in this tissue may not be advantageous. Indeed, as recently demonstrated in mouse tumor cell line (T $\alpha \mathrm{T} 1$ cells), some other physiological mechanisms may interfere with $\mathrm{T}_{4}$-induced $\mathrm{D} 2$ degradation (Christoffolete et al. 2006). In these cells, when a range of concentrations of $\mathrm{T}_{4}$ was used, the loss of $\mathrm{D} 2$ activity was impaired at a concentration $>50 \mathrm{pM}$. The potential explanation for this phenomenon is that the rate of D2 synthesis in these cells equals the maximal rate of $\mathrm{T}_{4}$-induced 

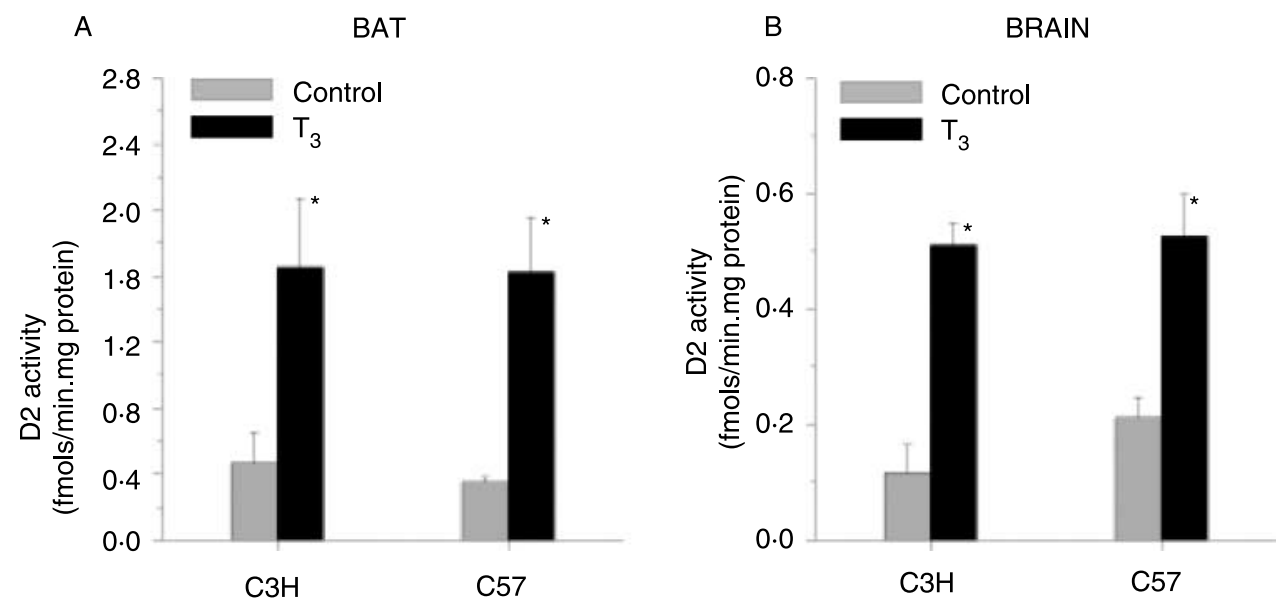

Figure 3 Effects of $\mathrm{T}_{3}$ treatment on D2 activity in brown adipose tissue (BAT) (A) and brain (B) of $\mathrm{C} 3 \mathrm{H}$ and C57 mice. Euthyroid mice were administered L-T $(10 \mu \mathrm{g} /$ animal) or vehicle (controls) by i.p. injection for 3 days. Values are the means \pm s.D. ${ }^{*} P<0 \cdot 01$ when compared with control.

D2 degradation, though the authors also considered a possible exhaustion of the ubiquitinating/proteolytic machinery. Although the mechanism whereby BAT D2 activity remains elevated when marked increases in serum $\mathrm{T}_{4}$ level are induced in euthyroid mice has not been determined in this study, it is conceivable that mechanisms similar to those observed in TaT1 cells may operate in this tissue. Furthermore, an increased rate of reactivation of ubiquitinated-D2 via von Hippel-Lindau protein-interacting deubiquinating enzyme (VDU)-1,2-mediated deubiquitination could be involved, since it has been shown that this system is very important in regulating the supply of active thyroid hormone in BAT (Curcio-Morelli et al. 2003). According to this line of reasoning, we can expect that in a setting of $\mathrm{T}_{4}$-induced hyperthyroidism, other mechanisms than inhibition of D2 are present in order to prevent BAT thyrotoxicosis. Indeed, previous studies have shown that infusion of high doses of $\mathrm{T}_{4}$ in rats did not decrease BAT D2 activity, whereas BAT $\mathrm{T}_{3}$ concentration remained normal or only slightly elevated (Escobar-Morreale et al. 1997).

The effect of $\mathrm{T}_{3}$ administration on D2 expression was also investigated in D1-deficient mice. Treatment of euthyroid mice with $\mathrm{T}_{3}$ results in a marked decrease in BAT D2 mRNA levels, whereas it did not significantly change cerebral D2 mRNA. As demonstrated in rats, the negative control of D2 expression in hypothyroid brain and pituitary by $\mathrm{T}_{3}$ is probably mediated by
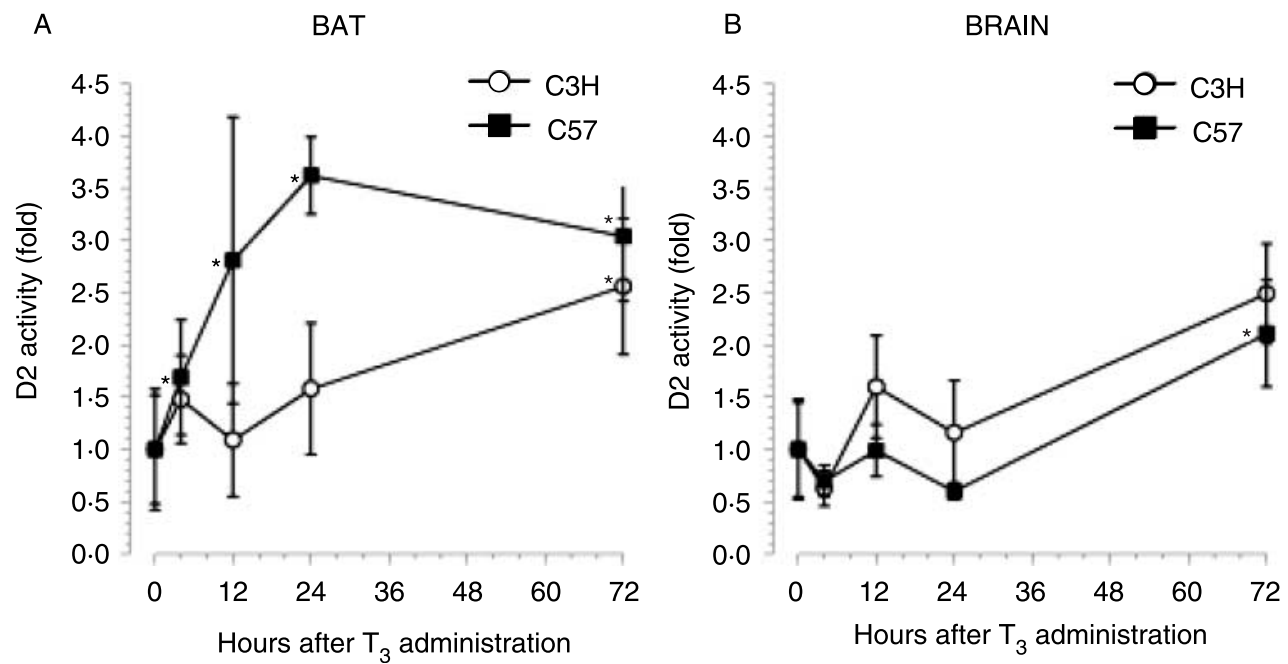

Figure 4 Time course of the induction on BAT (A) and brain (B) D2 activities by $\mathrm{T}_{3}$ administration in the $\mathrm{C} 3 \mathrm{H}$ and $\mathrm{C} 57$ mice. Euthyroid mice were administered $\mathrm{L}-\mathrm{T}_{3}(10 \mu \mathrm{g} / \mathrm{animal})$ or vehicle (controls) by i.p. injections for $4,12,24$, and $72 \mathrm{~h}$. Data are the means \pm s.D. shown relative to controls. ${ }^{*} P<0 \cdot 05$ versus zero time-point. 
Table 3 Serum thyroxine $\left(\mathrm{T}_{4}\right)$ and tri-iodothyronine $\left(\mathrm{T}_{3}\right)$ concentrations in control and $\mathrm{T}_{3}$-treated C3H and C57 mice. Values are mean \pm s.D. from determinations in three to five mice

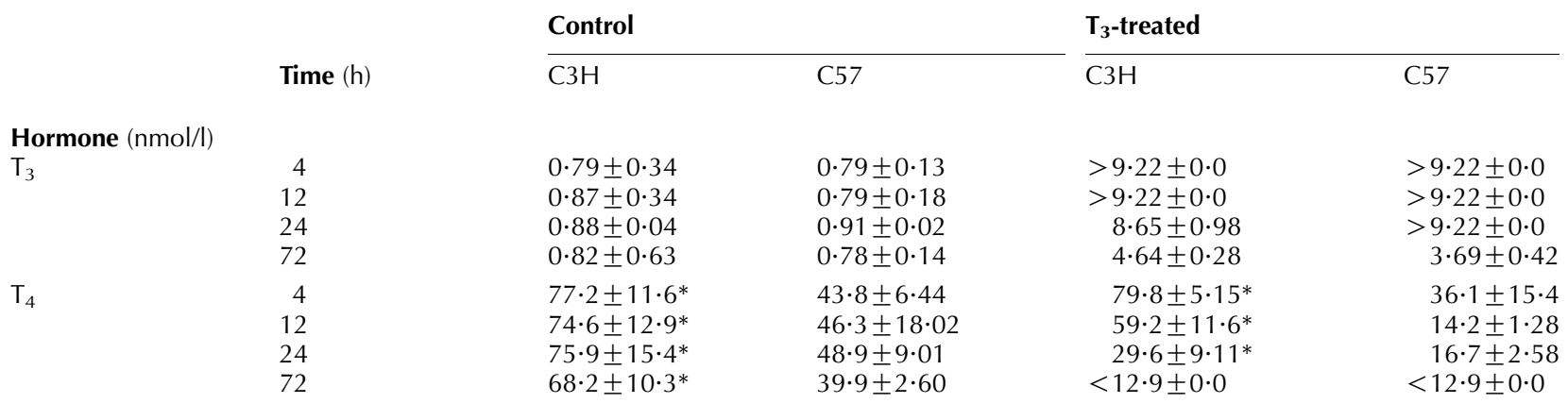

Animals were treated as described in Materials and Methods. *Significantly different from C57 $(P<0 \cdot 05)$.

the nuclear $\mathrm{T}_{3}$ receptor, although a putative negative TRE in the promoter region of the D2 gene remains to be identified (Burmeister et al. 1997, Kim et al. 1998). The lack of response of cerebral D2 mRNA to $\mathrm{T}_{3}$ treatment is in agreement with a previous study (Croteau et al. 1996) and is probably due to the near complete saturation of $\mathrm{T}_{3}$ receptors in brain of euthyroid mice (Larsen et al. 1981). On the other hand, in cultured rat brown adipocytes, $\mathrm{T}_{3}$ alone was shown to increase D2 mRNA but did not change significantly D2 activity levels (Martinez-deMena et al. 2002), indicating that discrepancies exist regarding the in vivo and in vitro effects of $\mathrm{T}_{3}$ on the regulation of D2 expression in BAT.

In contrast to the inhibitory effect of $\mathrm{T}_{3}$ administration on $\mathrm{D} 2$ mRNA expression, D2 activity levels were increased $\sim 2$ - to 3.5-fold in brain and BAT in both $\mathrm{C} 3 \mathrm{H}$ and $\mathrm{C} 57$ strains. Consideration of these data led to the hypothesis that induction of $\mathrm{D} 2$ activity in $\mathrm{T}_{3}$-treated mice was due to the decrease in serum $\mathrm{T}_{4}$ levels. Indeed, additional experiments demonstrated that the upregulation of $\mathrm{D} 2$ activity induced by $\mathrm{T}_{3}$ was offset by a concurrent decrease in serum $\mathrm{T}_{4}$ level and combined $\mathrm{T}_{3}$ plus $\mathrm{T}_{4}$ administration abolished $\mathrm{T}_{3}$-induce D2 increase (Fig. 4 and Table 4). Although these results are quite predictable, they were somewhat unexpected because most studies that evaluated $T_{3}$ effect on D2 activity were performed in hypothyroid animals and, in this setting, $\mathrm{T}_{3}$ administration decreases $\mathrm{D} 2 \mathrm{mRNA}$ and activity. In agreement with our results, elegant studies performed by Escobar-Morreale et al. (1997) have shown that in thyroidectomized rats, D2 activity returned to normal with $\mathrm{T}_{4}$ infusion, whereas it was increased in animals infused with $\mathrm{T}_{3}$, when compared with the activities found in animals infused with placebo. Taken together, these observations allow two other inferences. First, serum $\mathrm{T}_{3}$ has a minor role in regulating $\mathrm{D} 2$ at post-translational level. Second, the $\mathrm{T}_{4}$ downregulation of D2 activity is remarkable, since decreases in serum $\mathrm{T}_{4}$ level upregulate activity several times, regardless of the $T_{3}$-induced suppression of D2 mRNA synthesis.

$\mathrm{T}_{3}$ treatment also increases D2 activity in the brain of both strains. However, the time course and magnitude in response to $\mathrm{T}_{3}$ was nearly identical in control and D1-deficient mice. Another interesting observation was that the increase in D2 activity occurred later than that observed in the C57 BAT, which might indicate differences in the time required for the exchange of plasma/tissue $\mathrm{T}_{4}$ among the different tissues.

In conclusion, we demonstrated that D1 deficiency does not affect D2 mRNA levels, but differentially affects D2 activity in pituitary, brain, and BAT in the $\mathrm{C} 3 \mathrm{H}$ mice. While approximately twofold increase in serum $\mathrm{T}_{4}$ concentration is enough to induce a significant decrease in D2 activity levels in $\mathrm{C} 3 \mathrm{H}$ pituitary and brain, the $\mathrm{T}_{4}$-induced $\mathrm{D} 2$ downregulation in BAT requires a much higher serum $\mathrm{T}_{4}$ level. These results suggest that other intrinsic mechanisms prevent the loss of D2 activity in this tissue, probably to avoid a decrease in the D2-generated $T_{3}$ to supply nuclear $T_{3}$-receptor. Furthermore, we showed that administration of $\mathrm{T}_{3}$ to euthyroid mice

Table 4 Effects of combined thyroxine $\left(T_{4}\right)+$ tri-iodothyronine $\left(T_{3}\right)$ treatment on serum thyroid hormones concentration and brown adipose tissue (BAT) deiodinase (D2) activity. Values are the means \pm s.D. from determinations in four mice

\begin{tabular}{|c|c|c|c|c|}
\hline & Time $(h)$ & $\mathbf{T}_{\mathbf{3}}(\mathrm{nmol} / \mathrm{l})$ & $\mathbf{T}_{\mathbf{4}}(\mathrm{nmol} / \mathrm{l})$ & BAT D2 activity \\
\hline $\begin{array}{l}\text { (A) Control } \\
\mathrm{T}_{3}+\mathrm{T}_{4} \\
\text { (B) Control } \\
\mathrm{T}_{3}+\mathrm{T}_{4}\end{array}$ & $\begin{array}{r}6 \\
24\end{array}$ & $\begin{array}{l}1 \cdot 92 \pm 0 \cdot 42 \\
9 \cdot 99 \pm 0 \cdot 01^{*} \\
1 \cdot 52 \pm 0 \cdot 04 \\
7 \cdot 65 \pm 2 \cdot 24^{*}\end{array}$ & $\begin{array}{l}52 \cdot 7 \pm 6 \cdot 43 \\
86 \cdot 2 \pm 15 \cdot 4^{*} \\
51 \cdot 4 \pm 5 \cdot 15 \\
57 \cdot 9 \pm 10 \cdot 31\end{array}$ & $\begin{array}{l}0 \cdot 99 \pm 0 \cdot 26 \\
0 \cdot 85 \pm 0 \cdot 03 \\
0 \cdot 96 \pm 0 \cdot 10 \\
0 \cdot 97 \pm 0 \cdot 29\end{array}$ \\
\hline
\end{tabular}

C57 mice were injected a combination of $10 \mu \mathrm{g} \mathrm{T}_{3}+3 \mu \mathrm{g} \mathrm{T}_{4} / 100 \mathrm{~g}$ body weight and the circulating levels of thyroid hormones and D2 activity (fmol/min per mg protein) were determined (A) 6 or (B) $24 \mathrm{~h}$ after treatment. Control animals received the appropriate vehicle injections. *Significantly different from control $(P<0 \cdot 05)$. 
causes a tissue-specific modulation of D2 mRNA levels and increases D2 activity in BAT and brain. The latter $\mathrm{T}_{3}$ effect is rapid and marked, and seems to be the result of the decrease in serum $\mathrm{T}_{4}$ levels, rather than a direct effect of thyrotoxicosis.

\section{Acknowledgements}

We acknowledge the Conselho Nacional de Desenvolvimento Científico e Tecnológico (CNPq), Fundação de Amparo à Pesquisa do Estado do Rio Grande do Sul (FAPERGS), and Fundo de Incentivo a Pesquisa (FIPE), Brasil. The authors declare that there is no conflict of interest that would prejudice the impartiality of this scientific work.

\section{References}

Berry MJ, Kates AL \& Larsen PR 1990 Thyroid hormone regulates type I deiodinase messenger RNA in rat liver. Molecular Endocrinology 4 743-748. Berry MJ, Grieco D, Taylor BA, Maia AL, Kieffer JD, Beamer W, Glover E, Poland A \& Larsen PR 1993 Physiological and genetic analyses of inbred mouse strains with a type I iodothyronine $5^{\prime}$ deiodinase deficiency. Journal of Clinical Investigation 92 1517-1528.

Bianco AC \& Silva JE 1987 Nuclear 3,5,3-triiodothyronine $\left(T_{3}\right)$ in brown adipose tissue: receptor occupancy and sources of $T_{3}$ as determined by in vivo techniques. Endocrinology 120 55-62.

Bianco AC, Salvatore D, Gereben B, Berry MJ \& Larsen PR 2002 Biochemistry, cellular and molecular biology, and physiological roles of the iodothyronine selenodeiodinases. Endocrine Reviews 23 38-89.

Bianco AC, Maia AL, da Silva WS \& Christoffolete MA 2005 Adaptive activation of thyroid hormone and energy expenditure. Bioscience Reports 25 191-208.

Buchmann A, Bauer-Hofmann R, Mahr J, Drinkwater NR, Luz A \& Schwarz M 1991 Mutational activation of the $\mathrm{c}-\mathrm{Ha}$-ras gene in liver tumors of different rodent strains: correlation with susceptibility to hepatocarcinogenesis. PNAS 88 911-915.

Burmeister LA, Pachucki J \& St Germain DL 1997 Thyroid hormones inhibit type 2 iodothyronine deiodinase in the rat cerebral cortex by both pre- and posttranslational mechanisms. Endocrinology 138 5231-5237.

Christoffolete MA, Ribeiro R, Singru P, Fekete C, da Silva WS, Gordon DF, Huang SA, Crescenzi A, Harney JW, Ridgway EC et al. 2006 Atypical expression of type 2 iodothyronine deiodinase in thyrotrophs explains the thyroxine-mediated pituitary thyrotropin feedback mechanism. Endocrinology 147 1735-1743.

Crantz FR, Silva JE \& Larsen PR 1982 An analysis of the sources and quantity of 3,5,3-triiodothyronine specifically bound to nuclear receptors in rat cerebral cortex and cerebellum. Endocrinology 110 367-375.

Croteau W, Davey JC, Galton VA \& St Germain DL 1996 Cloning of the mammalian type II iodothyronine deiodinase. A selenoprotein differentially expressed and regulated in human and rat brain and other tissues. Journal of Clinical Investigation 98 405-417.

Curcio-Morelli C, Zavacki AM, Christofollete M, Gereben B, de Freitas BC, Harney JW, Li Z, Wu G \& Bianco AC 2003 Deubiquitination of type 2 iodothyronine deiodinase by von Hippel-Lindau protein-interacting deubiquitinating enzymes regulates thyroid hormone activation. Journal of Clinical Investigation 112 189-196.

Escobar-Morreale HF, Obregon MJ, Hernandez A, Escobar del Rey F \& Morreale de Escobar G 1997 Regulation of iodothyronine deiodinase activity as studied in thyroidectomized rats infused with thyroxine or triiodothyronine. Endocrinology 138 2559-2568.

Gereben B, Goncalves C, Harney JW, Larsen PR \& Bianco AC 2000 Selective proteolysis of human type 2 deiodinase: a novel ubiquitin-proteasomal mediated mechanism for regulation of hormone activation. Molecular Endocrinology 14 1697-1708.
Gereben B, Kollar A, Harney JW \& Larsen PR 2002 The mRNA structure has potent regulatory effects on type 2 iodothyronine deiodinase expression. Molecular Endocrinology 16 1667-1679.

St Germain DL 1988 The effects and interactions of substrates, inhibitors, and the cellular thiol-disulfide balance on the regulation of type II iodothyronine 5'-deiodinase. Endocrinology 122 1860-1868.

de Jesus LA, Carvalho SD, Ribeiro MO, Schneider M, Kim SW, Harney JW, Larsen PR \& Bianco AC 2001 The type 2 iodothyronine deiodinase is essential for adaptive thermogenesis in brown adipose tissue. Journal of Clinical Investigation 108 1379-1385.

Kim SW, Harney JW \& Larsen PR 1998 Studies of the hormonal regulation of type $25^{\prime}$-iodothyronine deiodinase messenger ribonucleic acid in pituitary tumor cells using semiquantitative reverse transcription-polymerase chain reaction. Endocrinology 139 4895-4905.

Kuiper GG, Klootwijk W \& Visser TJ 2002 Substitution of cysteine for a conserved alanine residue in the catalytic center of type II iodothyronine deiodinase alters interaction with reducing cofactor. Endocrinology 143 1190-1198.

Larsen PR, Silva JE \& Kaplan MM 1981 Relationships between circulating and intracellular thyroid hormones: physiological and clinical implications. Endocrine Reviews 2 87-102.

LeonardJL, SilvaJE, Kaplan MM, Mellen SA, Visser TJ \& Larsen PR 1984 Acute posttranscriptional regulation of cerebrocortical and pituitary iodothyronine 5'-deiodinases by thyroid hormone. Endocrinology 114 998-1004.

Maia AL, Harney JW \& Larsen PR 1995a Pituitary cells respond to thyroid hormone by discrete, gene-specific pathways. Endocrinology 136 1488-1494.

Maia AL, Berry MJ, Sabbag R, Harney JW \& Larsen PR $1995 b$ Structural and functional differences in the dio1 gene in mice with inherited type 1 deiodinase deficiency. Molecular Endocrinology 9 969-980.

Maia AL, Kim BW, Huang SA, Harney JW \& Larsen PR 2005 Type 2 iodothyronine deiodinase is the major source of plasma $T_{3}$ in euthyroid humans. Journal of Clinical Investigation 115 2524-2533.

Manning KL \& McDonald TP 1997 C3H mice have larger spleens, lower platelet counts, and shorter platelet lifespans than C57BL mice: an animal model for the study of hypersplenism. Experimental Hematology 25 1019-1024.

Martinez-deMena R, Hernandez A \& Obregon MJ 2002 Triiodothyronine is required for the stimulation of type II $5^{\prime}$-deiodinase mRNA in rat brown adipocytes. American Journal of Physiology. Endocrinology and Metabolism 282 E1119-E1127.

Paigen B, Albee D, Holmes PA \& Mitchell D 1987 Genetic analysis of murine strains $\mathrm{C} 57 \mathrm{BL} / 6 \mathrm{~J}$ and $\mathrm{C} 3 \mathrm{H} / \mathrm{HeJ}$ to confirm the map position of Ath-1, a gene determining atherosclerosis susceptibility. Biochemical Genetics 25 501-511.

Schneider MJ, Fiering SN, Pallud SE, Parlow AF, St Germain DL \& Galton VA 2001 Targeted disruption of the type 2 selenodeiodinase gene (DIO2) results in a phenotype of pituitary resistance to $\mathrm{T}_{4}$. Molecular Endocrinology 15 2137-2148.

Schneider MJ, Fiering SN, Thai B, Wu SY, St Germain E, Parlow AF, St Germain DL \& Galton VA 2006 Targeted disruption of the type 1 selenodeiodinase gene (Dio1) results in marked changes in thyroid hormone economy in mice. Endocrinology 147 580-589.

Schoenmakers CH, Pigmans IG, Poland A \& Visser TJ 1993 Impairment of the selenoenzyme type I iodothyronine deiodinase in $\mathrm{C} 3 \mathrm{H} / \mathrm{He}$ mice. Endocrinology 132 357-361.

Silva JE \& Larsen PR 1985 Potential of brown adipose tissue type II thyroxine $5^{\prime}$-deiodinase as a local and systemic source of triiodothyronine in rats. Journal of Clinical Investigation 76 2296-2305.

Silva JE \& Leonard JL 1985 Regulation of rat cerebrocortical and adenohypophyseal type II $5^{\prime}$-deiodinase by thyroxine, triiodothyronine, and reverse triiodothyronine. Endocrinology 116 1627-1635.

Silva JE, Dick TE \& Larsen PR 1978 The contribution of local tissue thyroxin monodeiodination to the nuclear 3,5,3-triiodothyronine in pituitary, liver, and kidney of euthyroid rats. Endocrinology 103 1196-1207.

Steinsapir J, Harney J \& Larsen PR 1998 Type 2 iodothyronine deiodinase in rat pituitary tumor cells is inactivated in proteasomes. Journal of Clinical Investigation 102 1895-1899. 
Steinsapir J, Bianco AC, Buettner C, Harney J \& Larsen PR 2000 Substrateinduced downregulation of human type 2 deiodinase (hD2) is mediated through proteasomal degradation and requires interaction with the enzyme's active center. Endocrinology 141 1127-1135.

Streckfuss F, Hamann I, Schomburg L, Michaelis M, Sapin R, Klein MO, Kohrle J \& Schweizer U 2005 Hepatic deiodinase activity is dispensable for the maintenance of normal circulating thyroid hormone levels in mice. Biochemical and Biophysical Research Communications 337 739-745.

Visser TJ 1996 Pathways of thyroid hormone metabolism. Acta Medica Austriaca 23 10-16.
Wagner MS, Morimoto R, Dora JM, Benneman A, Pavan R \& Maia AL 2003 Hypothyroidism induces type 2 iodothyronine deiodinase expression in mouse heart and testis. Journal of Molecular Endocrinology 31 541-550.

Received 28 February 2007

Accepted 2 April 2007

Made available online as an Accepted Preprint 3 April 2007 